\title{
Spatial distribution and diversity inventory of macro-benthic fauna in the Indian Sundarban
}

\author{
SUSOVAN SAU, T. S. NAGESH, R. K. TRIVEDI, T. J. ABRAHAM, S. K. DUBEY, \\ S. K. ROUT, I. BISWAS AND DIBAKAR BHAKTA* \\ Faculty of Fishery Sciences, West Bengal University of Animal and Fishery Sciences, Chakgaria, Kolkata - 700094 \\ West Bengal, India \\ *ICAR-Central Inland Fisheries Research Institute, Barrackpore, Kolkata - 700 120, West Bengal, India \\ e-mail: tsnagesh2@gmail.com
}

\begin{abstract}
In the present study, an attempt was made to document the spatial distribution and rapid diversity inventory of macro-benthic fauna from 21 sampling stations of the Indian Sundarban for a period of six months from November 2014 to April 2015. A total of 1,871 individuals belonging to 35 species were recorded which comprised 12 species of molluscs, 20 species of crustaceans, one species each of xiphosurid, sea anemone and fish. The frequency analysis of species revealed that the most dominant species were Telescopium telescopium and Tubuca rosea among molluscs and crustaceans, respectively. The density analysis of species showed that Pirenella cingulata and T. rosea had maximum values among molluscs and crustaceans, respectively. The average values of Shannon-Wiener diversity index, Simpson diversity index, dominance index and Margalef diversity index were found to be $2.712,0.888,0.111$ and 4.513 , respectively.
\end{abstract}

Keywords: Indian Sundarban, Macro-benthic fauna, Spatial distribution, Species diversity

\section{Introduction}

The Indian Sundarban $\left(21^{\circ} 32^{\prime}\right.$ to $22^{\circ} 40^{\prime} \mathrm{N}$ and $88^{\circ} 85^{\prime}$ to $89^{\circ} 00^{\prime} \mathrm{E}$ ), the largest delta in the estuarine phase of the tidal Hooghly River, has an area of $9,630 \mathrm{~km}^{2}$ and is situated in the east coast of India. Estuaries in general, and mangrove ecosystems in particular are highly productive systems and their sediments are permanently or periodically inhabited by diverse assemblages of benthic invertebrates like polychaetes, molluscs and crustaceans (Day et al., 1987). Macrobenthic organisms in estuaries are generally diverse and typically sedentary in nature (Prabhu et al., 1993). Understanding the biological diversity in terms of the processes by which ecosystems and their components function, is critical for its sustainable use. Macrobenthos play a major ecological role in the mangrove ecosystem by assisting in the breakdown of particulate organic material and exposing them to microbes (Warren and Underwood, 1986). Further, their waste materials contain rich nutrients supporting offshore and pelagic communities (Lee, 1997), thereby exporting energy to higher trophic level.

Small changes in the environment will have substantial response on the macrobenthos, which can be used as a potential indicator to measure the degree of pollution (Coull, 1973) and to assess health of ecosystem. The estimation of benthic production would also serve as a useful index for assessing the fishery potentials, interaction, pollution and intertidal ecology. Studies on benthic diversity, population dynamics and changes caused by natural or anthropogenic processes are therefore, essential for monitoring changes in mangrove ecosystems and its management (Jahan et al., 1990). Collection of data on spatial and temporal patterns are considered as a primary step in developing models about ecological processes within the ecosystem (Underwood et al., 2000) and to identify changes and assess impact of biotic and abiotic stress. Documentation of diversity will become an inevitable tool to understand status quo (Naeem et al., 1994). The present study, therefore was carried out to examine the mangrove associated macrobenthic faunal distribution and rapid diversity in Indian Sundarban.

\section{Materials and methods}

The present study was carried out for a period of six months, from November 2014 to April 2015. The total area of the Indian Sundarban (Fig. 1) was divided into three zones viz., Eastern, Central and Western zones and from each zone seven sampling sites (Table 1) were selected randomly. Samples were collected during low tide. For the quantitative study, sampling was made along the transects (100 $\mathrm{m}$ for each station) from the low tide mark. Further, $1 \mathrm{~m}$ quadrats constructed from nylon ribbon and bamboo sticks, were established along the transects with three replicates for each station. The quadrat was pushed into the sediment and the enclosed deposit was searched first and the deep burrowing organisms were counted 


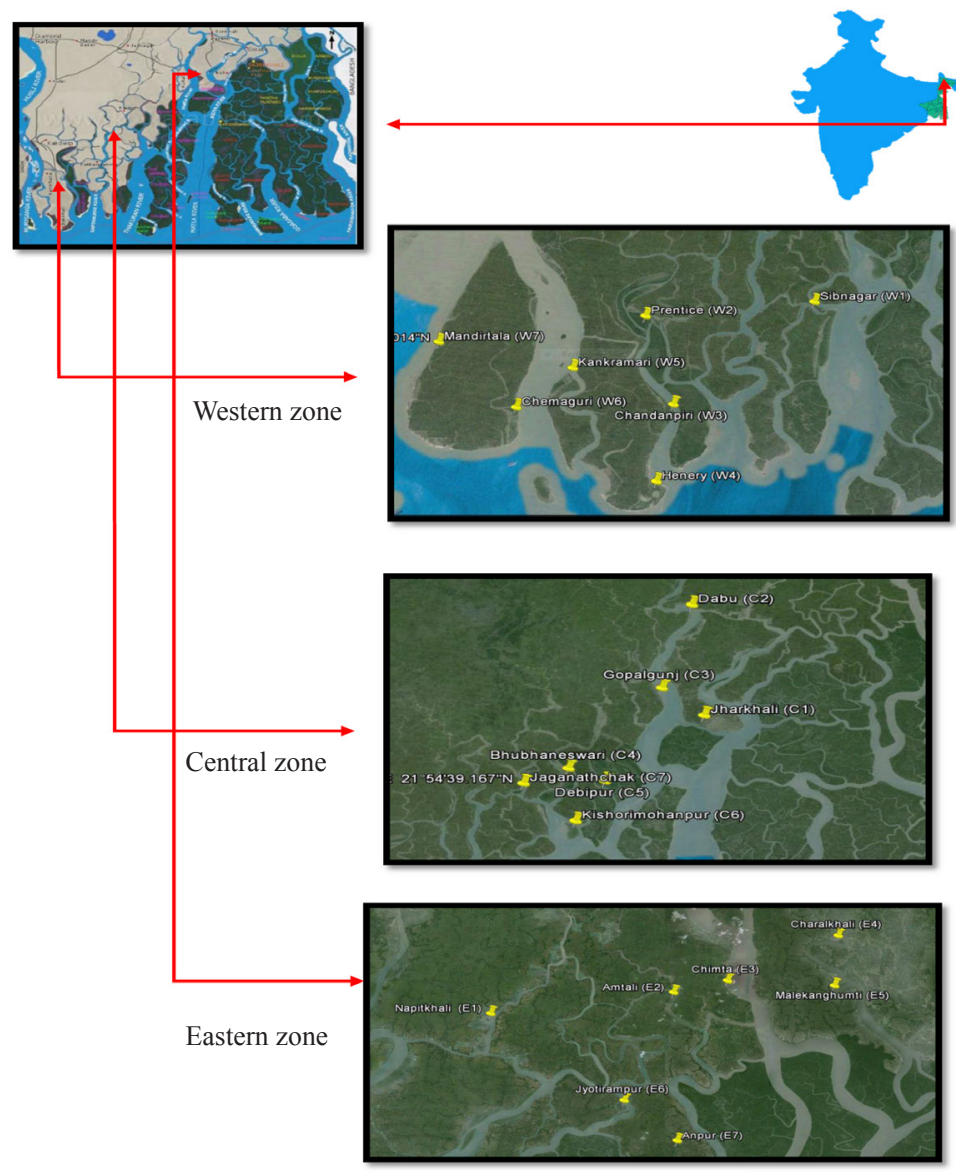

Fig. 1. Map showing sampling sites in the Indian Sundarban

by observing their burrows (Khade and Mane, 2012). Benthic fauna were then collected by digging the soil up to a depth at which no organisms were encountered. Soon after retrieval, the organisms were preserved in 5\% formalin and brought to the laboratory of Department of Fisheries Resource Management, Faculty of Fishery Sciences, West Bengal University of Animal and Fishery Sciences, Kolkata for further identification. The sorted organisms were first segregated into different groups and then identified to species or generic levels with the help of standard taxonomic references (Chakraborty et al., 1986; Dey, 2006). The present study, focused mainly on qualitative and quantitative assessments of benthic macrofauna viz., molluscs (bivalves, gastropods) and arthropods (crustaceans and xiphosurids). However, other mud dependent fauna were also recorded. The faunal densities are expressed as the number of animals per square metre.

\section{Diversity analyses}

Diversity analyses such as frequency and density of the species (Muller-Dombois and Ellenburg, 1974), Shannon-Wiener diversity index $(\mathrm{H})$ (Shannon and Wiener,
1949), dominance (D) as Simpson index (Simpson, 1949) and Margalef's index as a measure of species richness (Margalef, 1958) were carried out.

\section{Results and discussion}

Macrobenthos, the critical link in the mangrove ecosystem food web, inhabits the bottom of the water column and are visible to naked eye. They perform varieties of ecological functions including consumption of all kinds of organic matter and in turn act as food for many fishes, birds and other marine invertebrates. The important benthic faunal and ecological studies of mangrove swamps in Sundarban have been elucidated by earlier workers (Bhunia and Choudhury, 1981; Nandi and Choudhury, 1983; Dey, 2006; Sau et al., 2017). They opined that the distribution of macrobenthos was influenced by physicochemical and biological characteristics of the environment. In the present study, a total of 1,871 individuals belonging to 35 species were recorded from the 21 mangrove sampling stations of Indian Sundarban. Among them, 12 species were molluscs belonging to 8 families and 11 genera; 20 species were crustaceans belonging to 9 families and 15 genera and one 
Table 1. Details of sampling stations and geolocation

\begin{tabular}{|c|c|c|c|}
\hline Zone & Station code & Name & Geographical coordinates \\
\hline \multirow[t]{7}{*}{ Eastern } & E1 & Napitkhali & $88^{\circ} 44^{\prime} 48.58^{\prime \prime} \mathrm{E} ; 22^{\circ} 13^{\prime} 40.275^{\prime \prime} \mathrm{N}$ \\
\hline & E2 & Amtali, Taranagar & 88॰53'19.004”'E; 22॰14’48.447”N \\
\hline & E3 & Chimta & $88^{\circ} 55^{\prime} 48.165^{\prime \prime} \mathrm{E} ; 22^{\circ} 15^{\prime} 28.449 ” \mathrm{~N}$ \\
\hline & E4 & Charalkhali, Kanaikhati & $89^{\circ} 0{ }^{\prime} 59.0399^{\prime \prime} \mathrm{E} ; 22^{\circ} 17^{\prime} 52.156^{\prime \prime} \mathrm{N}$ \\
\hline & E5 & Malekanghumti & $89^{\circ} 0 ’ 48.335^{\prime \prime} \mathrm{E} ; 22^{\circ} 15^{\prime} 10.398^{\prime \prime} \mathrm{N}$ \\
\hline & E6 & Jyotirampur & 8850'14.158'”; 22॰8'8.129’N \\
\hline & E7 & Anpur & 88॰53’29.367’'E; 226’48.651”N \\
\hline \multirow[t]{7}{*}{ Central } & $\mathrm{C} 1$ & Jharkhali & $88^{\circ} 41^{\prime} 6.864 ” \mathrm{E} ; 22^{\circ} 1{ }^{\prime} 24.492^{\prime \prime N}$ \\
\hline & $\mathrm{C} 2$ & Dabu & $88^{\circ} 40^{\prime} 11.386^{\prime \prime} \mathrm{E} ; 22^{\circ} 12^{\prime} 26.368^{\prime \prime} \mathrm{N}$ \\
\hline & $\mathrm{C} 3$ & Gopalgunj & $88^{\circ} 37^{\prime} 51.765^{\prime \prime} \mathrm{E} ; 22^{\circ} 4^{\prime} 8.841^{\prime \prime} \mathrm{N}$ \\
\hline & $\mathrm{C} 4$ & Bhubhaneswari & $88^{\circ} 30^{\prime} 38.833^{\prime \prime} \mathrm{E} ; 21^{\circ} 56^{\prime} 8.652^{\prime \prime} \mathrm{N}$ \\
\hline & $\mathrm{C} 5$ & Debipur & 88³3’27.09”'E; 21॰54’52.911”N \\
\hline & C6 & Kishorimohanpur & 88॰31'11.306”'E; 21 ${ }^{\circ} 50^{\prime} 53.941^{\prime \prime} \mathrm{N}$ \\
\hline & $\mathrm{C} 7$ & Jaganathchak & 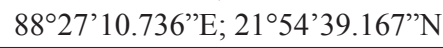 \\
\hline \multirow[t]{7}{*}{ Western } & W1 & Sibnagar & $88^{\circ} 27^{\prime} 4.154^{\prime \prime} \mathrm{E} ; 21^{\circ} 47^{\prime} 40.814^{\prime \prime} \mathrm{N}$ \\
\hline & W2 & Prentice & $88^{\circ} 16^{\prime} 45.548^{\prime \prime} \mathrm{E} ; 21^{\circ} 46^{\prime} 43.128^{\prime \prime} \mathrm{N}$ \\
\hline & W3 & Chandanpiri & $88^{\circ} 18^{\prime} 27.299^{\prime \prime} \mathrm{E} ; 21^{\circ} 40^{\prime} 26.936^{\prime \prime} \mathrm{N}$ \\
\hline & W4 & Henery & $88^{\circ} 17^{\prime} 26.502^{\prime \prime} \mathrm{E} ; 21^{\circ} 35^{\prime} 4.133^{\prime \prime} \mathrm{N}$ \\
\hline & W5 & Kankramari & 88॰12'20.86”'E; $21^{\circ} 43^{\prime} 0.707^{\prime \prime} \mathrm{N}$ \\
\hline & W6 & Chemaguri & 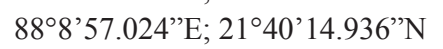 \\
\hline & W7 & Mandirtala, Harinbari & $88^{\circ} 4{ }^{\prime} 10.748^{\prime \prime} \mathrm{E} ; 21^{\circ} 44^{\prime} 52.014{ }^{\prime \prime} \mathrm{N}$ \\
\hline
\end{tabular}

species each of xiphosurid, sea anemone and fish (Table 2). The orders Littorinimorpha and Caenogastropoda were found to be dominant among molluscs with three species each, whereas the order Decapoda was dominant among crustaceans with 18 species (Fig. 2). Potamididae and Sesarmidae were the most dominant families among the molluscs and crustaceans with three and six species, respectively (Fig. 3).

Mangrove associated molluscs of India were studied by many workers (Ganapati and Rao, 1959; Radhakrishna and Janakiram, 1975; Mandal and Nandi,
1989; Ramamoorty and Rao, 1993; Rao, 2003; Dey, 2006; Saravanakumar et al., 2007, Venkatesan et al., 2010; Suresh et al., 2012; Satheeshkumar and Khan, 2012; Susan et al., 2012) and the total number of species reported varied between 9 and 70; gastropods being the dominant group. A comparison of the diversity of mangrove associated mollucscs of India reported by other researchers is given in Table 3. Though the species composition recorded by earlier authors could be comparable with the present study, the total number of species recorded during the present study is very low compared to earlier researchers.

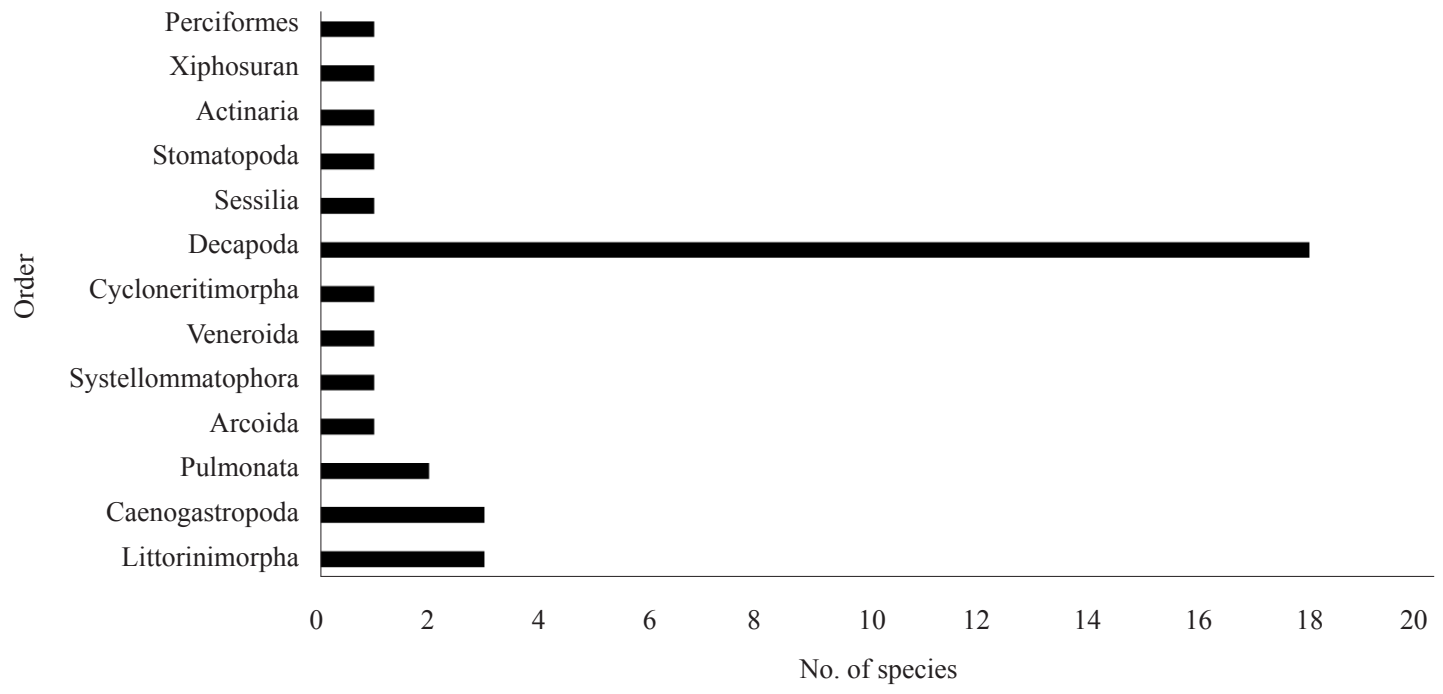

Fig. 2. Contribution of taxa by different orders in the Indian Sundarban 


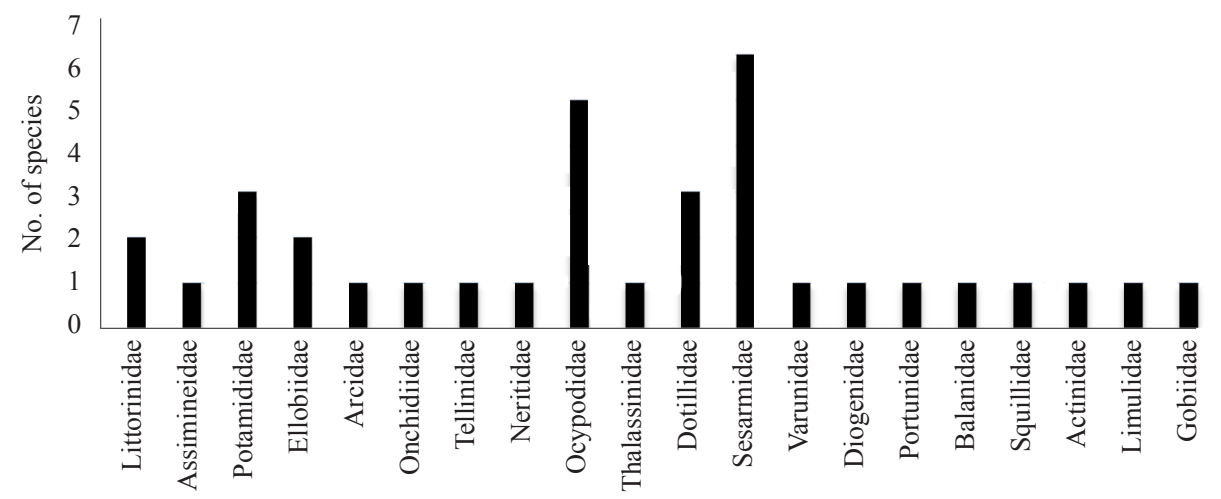

Fig. 3. Contribution of taxa by different families in the Indian Sundarban

Table 2. Checklist of macrobenthic fauna and their occurrence in Western, Central and Eastern zones of Indian Sundarban

\begin{tabular}{|c|c|c|c|c|c|c|c|}
\hline \multirow{2}{*}{ Phylum } & \multirow{2}{*}{ Class } & \multirow{2}{*}{ Order } & \multirow{2}{*}{ Family } & \multirow{2}{*}{ Scientific name } & \multicolumn{3}{|c|}{ Occurrence in zone } \\
\hline & & & & & $\mathrm{W}$ & $\mathrm{C}$ & E \\
\hline \multirow[t]{12}{*}{ Mollusca } & \multirow[t]{10}{*}{ Gastropoda } & \multirow[t]{3}{*}{ Littorinimorpha } & \multirow[t]{2}{*}{ Littorinidae } & Littoraria melanostoma (Gray, 1839) & - & +++ & ++ \\
\hline & & & & Littoraria scabra (Linnaeus, 1758) & ++ & + & + \\
\hline & & & Assimineidae & Austropilula beddomeana (G. Nevill, 1880) & + & + & + \\
\hline & & \multirow[t]{3}{*}{ Caenogastropoda } & \multirow[t]{3}{*}{ Potamididae } & Cerithidea obtusa (Lamarck, 1822) & +++ & +++ & ++ \\
\hline & & & & Pirenella cingulata (Gmelin, 1791) & +++ & +++ & ++ \\
\hline & & & & Telescopium telescopium (Linnaeus, 1758) & +++ & +++ & +++ \\
\hline & & \multirow[t]{2}{*}{ Pulmonata } & \multirow[t]{2}{*}{ Ellobiidae } & Pythia plicata (Ferussac, 1821) & + & + & + \\
\hline & & & & Cassidula nucleus (Gmelin, 1791) & + & + & + \\
\hline & & Cycloneritimorpha & Neritidae & Nerita balteata Reeve, 1855 & +++ & +++ & + \\
\hline & & Systellommatophora & Onchidiidae & Platevindex tigrinus (Stoliczka, 1869) & - & + & + \\
\hline & \multirow[t]{2}{*}{ Bivalvia } & Arcoida & Arcidae & Tegillarca granosa (Linnaeus, 1758) & + & + & + \\
\hline & & Veneroida & Tellinidae & Psammacoma sp. & + & + & + \\
\hline \multirow{10}{*}{$\begin{array}{l}\text { Arthropoda } \\
\text { (Sub phylum: } \\
\text { Crustacea) }\end{array}$} & \multirow{10}{*}{ Malacostraca } & \multirow[t]{10}{*}{ Decapoda } & \multirow[t]{5}{*}{ Ocypodidae } & Tubuca acuta (Stimpson, 1858) & - & - & + \\
\hline & & & & Tubuca rosea (Tweedie, 1937) & +++ & - & ++ \\
\hline & & & & Austruca lactea (De Haan, 1835) & ++ & + & + \\
\hline & & & & Austruca triangularis (A. Milne-Edwards, 1873) & ++ & ++ & + \\
\hline & & & & Tubuca dussumieri (H. Milne Edwards, 1852) & ++ & + & + \\
\hline & & & Thalassinidae & Thalassina anomala Herbst, 1804 & + & - & + \\
\hline & & & \multirow[t]{3}{*}{ Dotillidae } & Dotilla intermedia de Man, 1888 & - & - & + \\
\hline & & & & Dotilla blanfordi Alcock, 1900 & + & + & + \\
\hline & & & & Dotillopsis brevitarsis (de Man, 1888) & + & + & + \\
\hline & & & Sesarmidae & Sesarmoides sp. & - & - & + \\
\hline \multirow{10}{*}{$\begin{array}{l}\text { Arthropoda } \\
\text { (Sub phylum: } \\
\text { Crustacea) }\end{array}$} & \multirow{9}{*}{ Malacostraca } & \multirow[t]{8}{*}{ Decapoda } & \multirow[t]{5}{*}{ Sesarmidae } & Sesarmops impressus (H. Milne Edwards, 1837) & - & - & + \\
\hline & & & & Parasesarma bidens (De Haan, 1835) & ++ & + & + \\
\hline & & & & Episesarma mederi (H. Milne Edwards, 1853) & + & + & + \\
\hline & & & & Sesarmoides longipes (Krauss, 1843) & ++ & ++ & \\
\hline & & & & Parasesarma plicatum (Latreille, 1803) & + & + & + \\
\hline & & & Varunidae & Metaplax intermedia de Man, 1888 & + & ++ & + \\
\hline & & & Diogenidae & Clibanarius padavensis de Man, 1888 & ++ & ++ & ++ \\
\hline & & & Portunidae & Scylla serrata (Forskal, 1775) & ++ & ++ & ++ \\
\hline & & Stomatopoda & Squillidae & Squilla sp. & - & - & + \\
\hline & Maxillopoda & Sessilia & Balanidae & Balanus sp. Brown, 1844 & ++ & + & + \\
\hline $\begin{array}{l}\text { Arthropoda } \\
\text { Subphylum } \\
\text { Chelicerata }\end{array}$ & Merostomata & Xiphosurida & Limulidae & Carcinoscorpius rotundicauda (Latreille, 1802) & + & + & + \\
\hline Cnidaria & Anthozoa & Actiniaria & Actinidae & Sea anemone & + & - & - \\
\hline Chordata & Actinopterygii & Perciformes & Gobiidae & Boleophthalmus boddarti (Pallas, 1770) & + & + & + \\
\hline
\end{tabular}

W: Western zone, C: Central zone, E: Eastern zone

$+=$ Rare (Species represented in $1-7$ quadrats), $++=$ Common (Species represented in 8 - 14 quadrats), $++=$ Very common (Species represented in $14-21$ quadrats) 
Table 3. Mangrove associated molluses and crabs of India reported by other researchers

\begin{tabular}{|c|c|c|}
\hline Authors & Species reported & Study area \\
\hline \multicolumn{3}{|l|}{ Molluscs } \\
\hline Rao et al. (1983) & 21 species & $\begin{array}{l}\text { River Muriganga around } \\
\text { Kakdwip and Namkhana }\end{array}$ \\
\hline Dey et al. (2005) & 37 species ( 24 gastropods and 13 bivalves) & Sagar Island, West Bengal \\
\hline Dey (2006) & 56 species ( 31 gastropods and 25 bivalves) & Sundarban, West Bengal \\
\hline Saravanakumar et al. (2007) & 33 species (17 gastropods and 16 bivalves) & Gulf of Kachchh, Gujarat \\
\hline Roy et al. (2008) & 35 species ( 26 gastropods and 9 bivalves) & $\begin{array}{l}\text { Brackishwater wetlands, } \\
\text { West Bengal }\end{array}$ \\
\hline Satheeshkumar and Khan (2012) & 37 species (21 gastropods and 16 bivalves) & Pondicherry mangroves \\
\hline Paul et al. (2014) & 63 species (31 gastropods and 32 bivalves) & North-east coast of India \\
\hline Present study & 12 species ( 9 gastropods and 3 bivalves) & $\begin{array}{l}\text { Indian Sundarban, West } \\
\text { Bengal }\end{array}$ \\
\hline \multicolumn{3}{|l|}{ Crabs } \\
\hline Chakraborty et al. (1986) & 26 species & Sundarban, India \\
\hline Pandya and Vachhrajani (2013) & $\begin{array}{l}10 \text { species (dominant ones were Uca lactea annulipes, Macrophthalmus } \\
\text { depressus, Macrophthalmus brevis and Dotilla intermedia }\end{array}$ & $\begin{array}{l}\text { Mahi Estuary and } \\
\text { surrounding areas }\end{array}$ \\
\hline Present study & 18 species (dominant species was Tubuca rosea) & Indian Sundarban, India \\
\hline
\end{tabular}

Such variation could be attributed, firstly, to geographical variations of the study area, sampling design and duration of the investigation. Secondly, to the fact that the present study was aimed at recording the rapid diversity inventory based on quantitative samples collected from quadrats taken randomly at fixed depth without taking into account the specimen inhabiting outside the demarcated area. Contrary to this, other workers recorded all specimens occurring in wide habitats for a longer period.

In the present study, Cerithidea obtusa, Telescopium telescopium, Pirenella (=Cerithidea) cingulata and Nerita balteata (=Nerita articulata) were the most frequent species. Among molluscs, Telescopium telescopium was the most frequent species whereas Platevindex tigrinus was the least frequent one. Among crustaceans, Tubuca rosea was the most frequent one. The present findings are corroborated with the earlier findings of Roy et al. (2008) from the brackishwater wetlands of West Bengal who recorded Pirenella cingulata as the most dominant species in all the stations surveyed, whereas Cerithidea obtusa was dominant only in the lower littoral zone of the Matla River bed. Anbuchezhian et al. (2009) also observed that out of the 54 macrobenthic fauna in south-east coast of India, only a single species of gastropod $P$. cingulata dominated in all the stations surveyed, whereas, Das and Nandy (1999) have noted Littoraria scabra as the most abundant species in higher part of Sundarban mangroves.

Mangrove associated crustaceans, mainly represented by brachyuran crabs is considered not only as vital components influencing the structure and function of tropical mangrove forests, after bacteria and trees but also as bioindicators owing to their huge diversity, density and their unique preference to micro habitats (Lee, 1998; Arya et al., 2014).

In the present study, 20 species of crustaceans were reported out of which 18 species were crabs (Table 2). A comparison of the diversity of crabs reported by other researchers in Indian waters is given in Table 3. Sesarmids play an important role in the ecology of the mangroves through their selective destruction of propagules and huge consumption and breakdown of leaf litter (Robertson, 1986; Smith, 1987; Macintosh and Ashton, 2002). Other crustaceans include the portunids, hermit crabs, penaeid shrimps and a variety of burrowing species such as the mud lobster Thalassina, amphipods and isopods (Macintosh and Ashton, 2002).

Ocypodidae is dominated by the fiddler crabs $U c a$ spp., the density of which could be as high as $80 \mathrm{~m}^{-2}$ (Macintosh, 1984). Fiddler crabs also play an important role in the mangrove ecosystem as a food source for numerous predators (Macintosh and Ashton, 2002). Some mangrove crustaceans like the mud crab Scylla serrata which has considerable commercial value was also recorded in the present study. Some crustaceans can cause significant damage to mangroves, for example the barnacles (Balanus sp). Barnacles can damage or kill mangrove seedlings if in very high abundance (Macintosh and Ashton, 2002). Mudskippers, semi-terrestrial fish, are common representatives of teleosts in mangroves. In the present study Boleophthalmus boddarti was the only fish species recorded.

Abundance and composition of macrobenthos vary in the sampling stations due to the prevailing abiotic and biotic factors (Ramamurthy, 1953; Weyl and Peter, 
1970). However, an increase in marine invertebrate faunal diversity with the increase in number of plant species has also been well documented (Hutchings and Recher, 1983). Chakraborty (2013) has observed interactions of environmental variables determining the biodiversity of coastal-mangrove ecosystem of West Bengal, India. In fact, detritus provided by the mangrove vegetation charges the ambient water with nutrients, which trigger the growth of plankton and supplies food for the molluscan species. This may explain the relatively higher diversity value in the mangrove dominated stations.

In the present study, density of the species varied from $1.587 \mathrm{~m}^{-2}$ to $747.619 \mathrm{~m}^{-2}$. P. cingulata $\left(747.619 \mathrm{~m}^{-2}\right)$ and T. rosea $\left(119.048 \mathrm{~m}^{-2}\right)$ were the most dense mollusc and crustacean respectively (Fig. 4). Frequency of the species fluctuated between 1.587 and 90.476 (Fig. 5). The quantitative studies on the benthic macrofauna of Sagar Island was done by Nandi and Choudhury (1983) and the estimated faunal density varied from $82.8 \mathrm{~m}^{-2}$ to $328.95 \mathrm{~m}^{-2}$. Roy et al. (2008) revealed the highest population density of macrozoobenthic molluses at Canning $\left(2014.81 \mathrm{~m}^{-2}\right)$ in post-monsoon season and at Matla Char $\left(507.41 \mathrm{~m}^{-2}\right)$ in monsoon season. The present findings were corroborated with the earlier findings of Roy et al. (2008) and Islam et al. (2013) with respect to the frequency of the species.

Results of the present study revealed a comparatively higher density of species in the Western zone which decreased gradually towards the Eastern zone. Among the threezones, Western zone contributed the maximum number of individuals (748) followed by Central (612) and Eastern zones (511) (Fig. 6). Conversely, the maximum number of species was represented by Eastern zone (34), followed by Western zone (29) and Central zone (28) (Fig. 7). Benthic molluscan assemblages showed almost similar pattern of distribution in each zone (Eastern, Central and Western) except for P. tigrinus, which was not found in the Western zone. However, frequent occurrences of crustaceans were recorded. The species T. acuta, Dotilla intermedia, Sesarmoides sp. Sesarmops impressus and Squilla sp. were found only in the Eastern zone. Sea anemone was found only in the Western zone, and absent in Central and Eastern zones. Likewise, Thalassina anomala

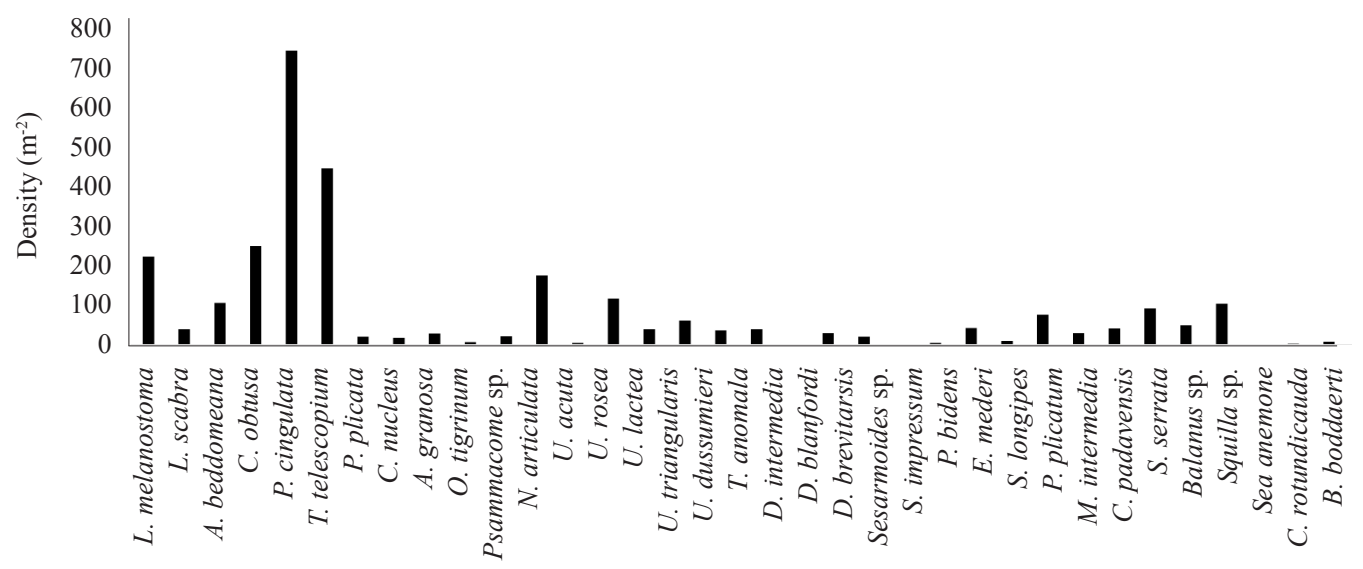

Fig. 4. Density of species in the Indian Sundarban

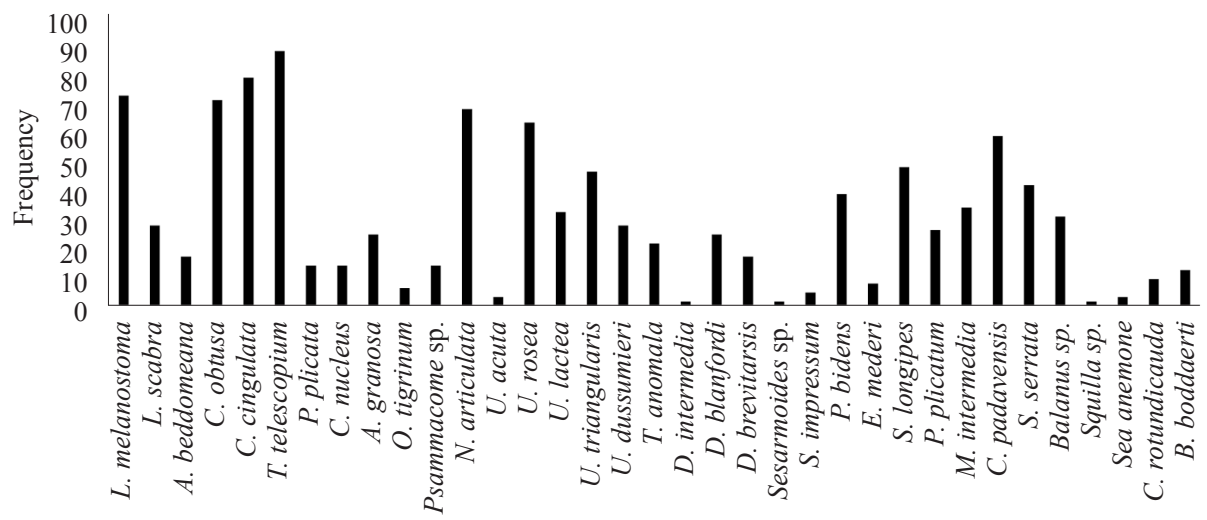

Fig. 5. Frequency of species in the Indian Sundarban 


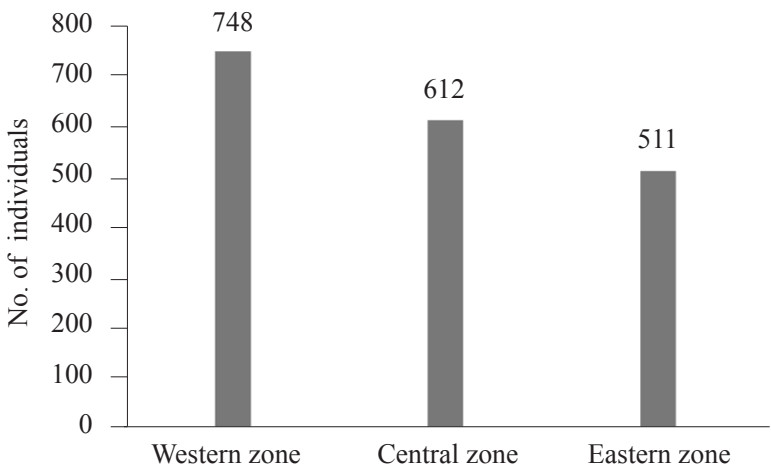

Fig. 6. Number of individuals recorded in different zones of Indian Sundarban

was not recorded in the Central zone of Indian Sundarban (Table 2) during the present study. The higher frequency of crustaceans in the Western zone indicated that the mangroves of this region are rich in organic food material thereby providing suitable habitats for them. The other main environmental factors affecting the distribution and structure of macrobenthic organisms reported by most authors are organic matter, salinity and sediment characteristics, especially mud and clay content (Parsons et al., 1984), the vegetation structure and composition (Kissling et al., 2012) and the sediment texture (Sanders, 1958). The most widely accepted model was proposed by Rosenberg (2001), who suggested that as the organic matter content increases, the species diversity decreases and the number of individuals increases. The salinity in Western zone is less compared to the salinities of Central and Eastern zones of Indian Sundarban. This may be one of the reasons for higher population density recorded in the Western zone.

The value of Shannon-Wiener diversity index in the entire study area varied from 1.322 to 2.928 which was similar to the value $(1.80-2.83)$ previously reported in the Pondicherry mangrove forest by Kumar and Khan (2013). Among the three zones studied, the Western zone showed maximum value of Shannon diversity index (2.756) followed by Eastern zone (2.619) and Central zone (2.573). This indicates that the degree of evenness in species abundance is better in Western zone compared to Eastern and Central zones of Indian Sundarban and also expressed that the interaction of species with ecosystem is better in Western zone.

Wilhm and Dorris (1966) proposed that the values of Shannon diversity index less than 1.0 for estuarine waters indicate heavy pollution, while values between 1.0 and 3.0 indicate moderate pollution, and values exceeding 3.0 indicate that the area is non-polluted. Therefore, it appears that the estuarine area of Western zone is comparatively

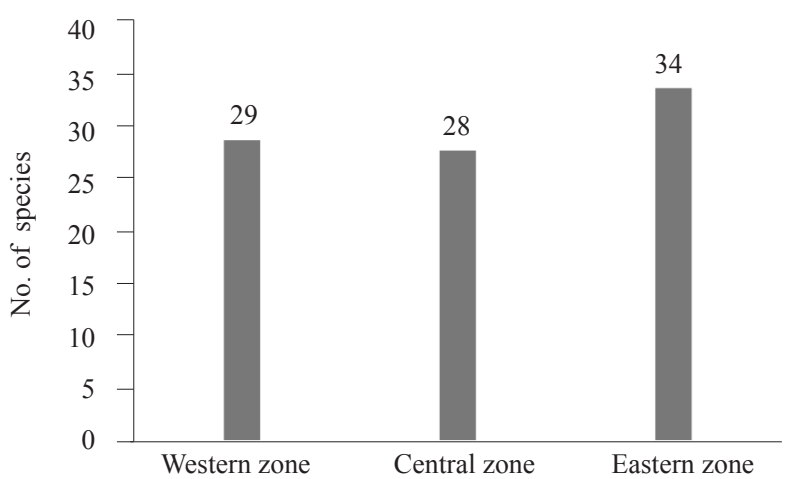

Fig. 7. Number of species recorded in different zones of Indian Sundarban

less polluted than the Eastern and Central zones of Indian Sundarban. It is also observed that the human settlement and anthropogenic activities are comparatively more in Central and Eastern zones of Indian Sundarban. Human activities have a strong influence on the aquatic environment in the south-east coast of Bay of Bengal (Ananthan et al., 2005).

In the study area, the dominance of macrobenthic fauna ranged between 0.069 and 0.381 , which was similar to the previous report by Kumar and Khan (2013) in the Pondicherry mangrove forest. The dominance index of macrobenthic fauna in Central zone $(0.131)$ was more compared to the Eastern (0.123) and Western (0.094) zones. It suggested that the Western zone of Indian Sundarban was more diverse followed by the Eastern and Central zones. It may be due to the diverse and dense mangrove forest present in the Western zone that supply food to the macrobenthic fauna.

The Simpson diversity index of macrobenthic fauna in Indian Sundarban varied from 0.619 to 0.931 . Among the three zones, the Western zone showed the maximum value of Simpson diversity index (0.905) followed by Eastern zone (0.876) and Central zone (0.868). It represents the probability that two individuals randomly selected from a sample will belong to different species. So, in the present study, the Western zone represented the maximum species diversity followed by Eastern and Central zones. It may be due to less competition among macrobenthos for space and food and also availability of suitable substrate for settlement in the Western zone compared to the Central and Eastern zones. According to Ramamurthy (1953), the abundance and composition of macrobenthos varied among the stations due to the prevailing abiotic and biotic factors. Biotic factors that affect the living organisms in the intertidal zone are competition for space and food, predation, reproduction substrate and settlement preference. Abiotic factors that affect the living organisms 
in the intertidal area are salinity, temperature, air and light exposure, tidal flow, waves and current action, substrate, wind direction and strength, dissolved oxygen, storms and natural disasters (Weyl and Peter, 1970).

The value of Margalef diversity index in the entire study area of Indian Sunderban varied from 0.973 to 5.477, which was relatively more compared to the value $(0.450$ to $0.720)$ previously reported in the Pondicherry mangrove forest by Kumar and Khan (2013). The Eastern zone showed the maximum value of Margalef diversity index (5.292), followed by Western zone (4.231) and Central zone (4.208). The Margalef diversity index has no limit value and it shows variation depending upon the number of species and is used for comparison of the sites..

The results obtained for Shanon-Wiener and Simpson indices showed higher values in the Western zone suggesting that this zone is more diverse and have even abundance of species than the other two zones. Low value of dominance (D), the reciprocal of Simpson's Index, recorded for the Western zone further corroborates the above findings. On the other hand, Margalef's species richness index, which is a direct measure of the number of species present at a site, was higher for Eastern zone, as the number of species recorded in Eastern zone was more.

The present study provides baseline information on the distribution, abundance and diversity of macrobenthic fauna in the Indian Sundarban. The findings indicate that the faunal community comprising of variety of species form an integral component of the mangrove ecosystem, but the degree of association and adaptation to such an environment differed from species to species. The information generated in this study will be of much use in formulating an action plan for the conservation and management of this sensitive and biodiversity rich ecosystem.

\section{Acknowledgements}

The authors are grateful to the National Centre for Sustainable Coastal Management (NCSCM), Chennai for financing the present study.

\section{References}

Ananthan, G., Sampathkumar, A., Soundarapandian, P. and Kannan, L. 2005. Observation on environmental characteristics of Ariyankuppam Estuary and Veerampattinam coast of Pondicherry, Indian J. Aquat. Biol., 19: 67-72.

Anbuchezhian, R. M., Rameshkumar, G. and Ravichandran, S. 2009. Macrobenthic composition and diversity in the coastal belt of Thondi, southeast coast of India. Global J. Environ. Res., 3(2): 68-75.
Arya, S., Trivedi, J. N. and Vachhrajani, K. D. 2014. Brachyuran crabs as a biomonitoring tool: A conceptual framework for chemical pollution assessment. Int. Res. J. Environ. Sci., 3(1): 49-57.

Bhunia, A. B. and Choudhury, A. 1981. Observations on the hydrology and the quantitative studies on benthic macrofauna in a tidal creek of Sagar Island, Sundarbans, West Bengal, India. Proc. Indian Natl. Sci. Acad. B., 47(3): 398-407.

Chakraborty, S. K. 2013. Interactions of environmental variables determining the biodiversity of coastal-mangrove ecosystem of West Bengal, India. The Ecoscan, 3: 251-265.

Chakraborty, S. K., Choudhury, A. and Deb, M. 1986. Decapoda brachyura from Sunderbans Mangrove Estuarine Complex, India. J. Bengal Nat. Hist. Soc., 5(1): 55-68.

Coull, B. C. 1973. Estuarine meiofauna, a review: Trophic relationships and microbial interactions. In: Stevens, L. H. and Colwell, R. R. (Eds.), Estuarine microbial ecology, Belle Baruch Coastal Research Institute, University of South Carolina, USA, p. 499-511.

Das, A. K. and Nandy, N. C. 1999. Fauna of the Indian Sundarbans Mangal and their role in the ecosystem. In: Guha Bakshi, D. N., Sanyal, P. and Naskar, K. R. (Eds), Sundarbans Mangal. Naya Prakash, Calcutta, India, p. 417-427.

Day, J. W., Hall, C. A. S., Kemp, W. M. and Yanez-Arancibia, A. 1987. Estuarine ecology. John Wiley and Sons, Brisbane, Australia, $558 \mathrm{pp}$

Dey, A. 2006. Handbook on mangrove associate molluscs of Sundarbans. Zoological Survey of India, Kolkata, India, $96 \mathrm{pp}$.

Dey, M., Jamader, Y. A. and Mitra, A. 2005. Distribution of intertidal malacofauna at Sagar Islands. Rec. Zool. Soc. India, 105(1\&2): 25-35.

Ganapati, P. N. and Rao, M. V. L. 1959. Incidence of marine borers in the mangroves of the Godavari Estuary. Curr. Sci., 28(8): 332-332.

Hutchings, P. A. and Recher, H. F. 1983. The faunal communities of Australian mangroves. In: Teas, H. J. (Ed.), Biology and ecology of mangroves, Dr. W. Junk Publishers, Hague, The Netherlands, p. 103-110.

Islam, M. S., Sikder, M. N. A., Al-Imran, M., Hossain, M. B., Mallick, D. and Morshed, M. M. 2013. Intertidal macrobenthic fauna of the Karnafuli Estuary: Relations with environmental variables. World Appl. Sci. J., 21(9): 1366-1373.

Jahan, M. S., Mannan, M. and Mandal, K. N. 1990. Intertidal molluscs of Sunderbans, Bangaladesh. Env. Ecol., 8(2): 603-607.

Khade, S. N. and Mane, U. H. 2012. Diversity of bivalve and gastropod molluscs of some localities from Raigad District, Maharashtra, west coast of India. Recent Res. Sci. Technol., 4(10): 43-48. 
Kissling, W. D., Sekercioglu, C. H. and Jetz, W. 2012. Bird dietary guild richness across latitudes, environments and biogeographic regions. Glob. Ecol. Biogeogr., 21: 328-340.

Kumar, P. S. and Khan, A. B. 2013. The distribution and diversity of benthic macroinvertebrate fauna in Pondicherry mangroves, India. Aquat. Biosyst., 9(15): 1-18.

Lee, S. Y. 1997. Potential tropic importance of the faecal material of the mangrove sesarmine crab. Mar. Ecol. Prog. Ser., 159: $275-284$.

Lee, S. Y. 1998. Ecological role of grapsid crabs in mangrove ecosystems: A review. Mar. Freshwat. Res., 49: 335-343.

Macintosh, D. J. 1984. Ecology and productivity of Malaysian mangrove crab populations (Decapoda: Brachyura). In: Soepadmo, E., Rao, A. N. and Macintosh, D. J. (Eds.), Proceedings of the Asian Symposium on mangrove environment, research and management. University of Malaysia and UNESCO, Kuala Lumpur, Malaysia, p. 354-377.

Macintosh, D. J. and Ashton, E. C. 2002. A review of mangrove biodiversity conservation and management. Centre for Tropical Ecosystems Research, University of Aarhus, Denmark, 71 pp.

Mandal, A. K. and Nandi, N. C. 1989. Fauna of Sundarban mangrove ecosystem, West Bengal, India, vol. 3,. Zoological Survey of India, Kolkata, India, 97 pp.

Margalef, R. 1958. Temporal succession and spatial heterogeneity in phytoplankton. In: Buzzati-Traverso (Ed.), Perspectives in marine biology. University of California Press, Berkeley, USA, p. 323-347.

Muller-Dombois, D. and Ellenburg, H. 1974. Aims and methods of vegetation ecology. Wiley and Sons, New York, USA.

Naeem, S., Thompson, L. J. and Lawler, S. P. 1994. Declining biodiversity can alter the performance of ecosystems. Nature, 368: 734-737.

Nandi, S. and Choudhury, A. 1983. Quantitative studies on the benthic macrofauna of Sagar Island, intertidal zones, Sunderbans, India. Mahasagar-Bull. Nat. Inst. Oceanogr., 16(3): 409-414

Pandya, P. J. and Vachhrajani, K. D. 2013. Brachyuran crab diversity of lower estuarine mud flats of Mahi River with new record of two species from Gujarat, India. Arthropods, 2(4): 242-250.

Parsons, T. R., Takahashi, M. and Hargrave, B. 1984. Biological oceanographic process. Pergamon Press, London, UK, 332 pp.

Paul, P., Panigrahi, A. K. and Tripathy, B. 2014. A study of marine molluscs with respect to their diversity, relative abundance and species richness in North-East coast of India. Indian J. Appl. Res., 4(12): 538-541.

Prabhu, V. H., Narayana, A. C. and Katti, R. J. 1993. Macrobenthic fauna in nearshore sediments of Gangolli, west coast of India. Indian J. Mar. Sci., 22: 168-171.
Radhakrishna, Y. and Janakiram, K. 1975. The mangrove molluscs of Godavari and Krishna estuaries. In: Natarajan, R. (Ed.), Recent researches in estuarine biology. Hindustan Publishing Corporation, New Delhi, India, p. 177-184.

Ramamoorty, K. V. and Rao, B. K. 1993. Studies on mangroves ecosystems of Godavari and Krishna estuaries, Andhra Pradesh, India. UNESCO Curriculum Workshop on Management of Mangrove Ecosystem and Coastal Production, 6-12 December 1993, Andhra University, Visakhapatnam, India, p. 21

Ramamurthy, S. 1953. Hydrobiological studies in the Madras coastal water. J. Madras Univ., 13(23): 148-163.

Rao, N. V. S. 2003. Indian seashells. Part 1. Polyplacophora and Gastropoda. Rec. Zool. Surv. India, Occasional Paper, 192: $416 \mathrm{pp}$.

Rao, S. N. V., Dey, A. and Barua, S. 1983. Studies on the malacofauna of Muriganga Estuary, Sundarbans, West Bengal, Bull. Zool. Surv. India, 5(1): 47-56.

Robertson, A. I. 1986. Leaf-burying crabs: Their influence on energy flow and export from mixed mangrove forests (Rhizophora spp.) in northeastern Australia. J. Exp. Mar. Biol. Ecol., 102: 237-248. https://doi.org/10.1016/00220981(86)90179-6.

Rosenberg, R. 2001. Marine benthic faunal successional stages and related sedimentary activity. Sci. Mar., 65(2): 107-119. DOI: $10.3989 /$ scimar.2001.65s 2107.

Roy, M., Dey, A., Banerjee, S. and Nandi, N. C. 2008. Molluscan macrobenthic diversity of brackishwater wetlands in West Bengal. Zool. Res. Hum. Wel., 11: 25-34.

Sanders, H. L. 1958. Benthic studies in Buzzards Bay, I. Animalsediment relationships. Limnol. Oceanogr., 3(3): 245-258. https://doi.org/10.4319/1o.1958.3.3.0245.

Saravanakumar, A., Sesh, S. J., Thivakaran, A. and Rajkumar, M. 2007. Benthic macrofaunal assemblage in the arid zone mangroves of Gulf of Kachchh-Gujarat. J. Ocean Univ. China, 6: 303-309.

Satheeshkumar, P. and Khan, A. B. 2012. Influence of environmental parameters on the distribution and diversity of molluscan composition in Pondicherry mangroves, southeast coast of India. Ocean Sci. J., 47(1): 61-71. DOI: 10.1007/s12601-012-0006-6.

Sau, S., Nagesh, T. S., Trivedi, R. K., Dubey, S. K., Rout, S. K., Biswas, I. and Dibakar Bhakta 2017. Species composition and habitats of macro-benthic crustaceans in the intertidal zones of Sundarban, West Bengal, India. J. Expt. Zool. India, 20(2): 1103-1107.

Shannon, C. E. and Wiener, W. 1949. The mathematical theory of communication. University of Illinois Press, Urbana, USA.

Simpson, E. H. 1949. Measurement of diversity. Nature, 163: 688. https://doi.org/10.1038/163688a0. 
Smith, T. J. 1987. Seed predation in relation to tree dominance and distribution in mangrove forests. Ecology, 68: 266-273. https://doi.org/10.2307/1939257.

Suresh, M., Arularasan, S. and Ponnusamy, K. 2012. Distribution of molluscan fauna in the artificial mangroves of Pazhayar backwater canal, southeast coast of India. Adv. Appl. Sci. Res., 3(3): 1795-1798.

Susan, V. D., Pillai, N. G. K. and Satheeshkumar, P. 2012. A checklist and spatial distribution of molluscan fauna in Minicoy Island, Lakshadweep, India. World J. Fish. Mar. Sci., 4(5): 449-453. DOI: 10.5829/idosi.wjfms.2012.04.05.63165.

Underwood, A. J., Chapman, M. G. and Connell, S. D. 2000. Observations in ecology: You can't make progress on processes without understanding the patterns. J. Exp. Mar. Biol. Ecol., 250: 97-115. DOI: 10.1016/s00220981(00)00181-7.
Venkatesan, V., Kalidas, C., Zacharia, P. U. and Rajagopal, S. 2010. Distribution of molluscan fauna in the Karangad estuarine mangroves, south-east coast of India. AES Bioflux, 2(2): 113-119.

Warren, J. H. and Underwood, A. J. 1986. Effects of burrowing crabs on the topography of mangrove swamps in New South Wales. J. Exp. Mar. Biol. Ecol., 102: 223-235. https://doi.org/10.1016/0022-0981(86)90178-4.

Weyl, A. and Peter, K. 1970. Oceanography - An introduction to the marine environment: Mostly physical, chemical and geological with some biology and ecology. Prentice-hall, New York, USA, 535 pp.

Wilhm, J. L. and Dorris, T. C. 1966. Species diversity of benthic macro-invertebrates in a stream receiving domestic and oil refinery effluents. J. Exp. Mar. Biol. Ecol., 76: 427-449. https://doi.org/10.2307/2423096. 